\title{
Histomorphometric and Immunohistochemical Study of Early Adaptative Response of the Vascular Wall in a Termino-Terminal Microsurgical Model of Femoral Vessels in Wistar Rat
}

\author{
Estudio Histomorfométrico e Inmunoistoquímico de la Respuesta Adaptativa Temprana de la Pared \\ Vascular en un Modelo Microquirúrgico Termino-Terminal de los Vasos Femorales en Rata Wistar
}

Sergio E. Velazquez-Gauna ${ }^{1}$; Adolfo Soto-Domínguez ${ }^{2}$; Alejandro Quiroga-Garza ${ }^{1}$; Cynthia G. Reyes-Hernández ${ }^{1}$; Arturo ChavezReyes $^{3}$; Rodolfo Morales-Avalos ${ }^{4}$; Roberto Montes-de-Oca-Luna ${ }^{1}$; Santos Guzmán-López ${ }^{1}$ \& Rodrigo E. Elizondo-Omaña ${ }^{1}$

VELAZQUEZ-GAUNA, S. E.; SOTO-DOMÍNGUEZ, A.; QUIROGA-GARZA, A; REYES-HERNÁNDEZ, C. G.; CHAVEZ-REYES, A.; MORALES-AVALOS R.; MONTES-DE-OCA-LUNA, R.; GUZMÁN-LÓPEZ, S. \& ELIZONDO-OMAÑA, R. E. Histomorphometric and immunohistochemical study of early adaptative response of the vascular wall in a termino-terminal microsurgical model of femoral vessels in wistar rat. Int. J. Morphol., 35(2):479-487, 2017.

SUMMARY: When a vein segment is grafted into arterial circulation, biomechanical forces stimulate modification of its structure. This morphological adaptive response is progressive during a medium or long term and occludes the vessel lumen, leading to a graft failure. The objective of this study was to characterize the early morphological response of the vascular wall in a terminal-terminal vascular vein graft model in Wistar rats. A segment of the femoral vein was placed in the femoral circulation. An end to end microsurgical graft anastomosis technique was implemented and standardized in twenty rats. The samples were processed with histological technique to analyze the overall structure with hematoxylin and eosin, the composition of the vessel wall with Masson trichrome technique, the proliferating and smooth muscle cells were detected with immunohistochemistry (anti-PCNA, anti-actin and anti CD68) and the induction of apoptosis with TUNEL technique. The times periods studied were 1, 3 and 5 days postoperative. There is progressive increase of cell proliferation and intensity of the density detected by PCNA with its peak at postoperative day 3. Apoptosis was not evident in any of the postoperative days. Smooth muscle had no significant change in any of the time periods studied. Macrophage and leukocyte migration was evident since the first postoperative day with infiltration into the media by the 5th day. This study characterizes the morphological aspects in the early arterialization of the vascular wall in a vein graft process. These results contribute to a better understanding of the morphopathological mechanism involved in vein graft failure.

KEY WORDS: Hyperplasia; Morphology; Microsurgical model; Vascular adaptive changes; Venous graft.

\section{INTRODUCTION}

Patients with ischemic heart disease may undergo surgical or medical treatments. Medical treatment includes changing eating habits, exercise, reduce cardiovascular risk factors and pharmacological treatment (Isselbacher et al., 1994). Surgical treatment may vary from a percutaneous transluminal coronary angioplasty to a coronary artery bypass.

Revascularization involves using a conduit as a graft in the vascular system to create an appropriate blood flow route to bypass an obstruction and provide irrigation to the surrounding ischemic tissues (Schwartz, 1995). This procedure involves the anastomosis of a vessel segment to a healthy artery with adequate irrigation, to a point distal to the obstruction where the ischemic tissue is present (AguirreRivero, 2003). For this, autologous vascular grafts are the preferred option, this involves using a vascular conduit from the same patient, either arterial or venous. The most frequently used ducts are, in order of importance: internal thoracic artery, saphenous vein, radial artery, right gastroepiploic artery, ulnar artery and to a lesser extent, the splenic artery and inferior epigastric artery (Elizondo-Omaña et al., 2005).

Despite the long-term outcomes superiority of the arterial grafts, autologous venous vessels, such as the

\footnotetext{
${ }^{1}$ Department of Human Anatomy, Faculty of Medicine, Universidad Autónoma de Nuevo León (U.A.N.L.), Monterrey, Nuevo León, México.

${ }^{2}$ Department of Histology, Faculty of Medicine, Universidad Autónoma de Nuevo León (U.A.N.L.), Monterrey, Nuevo León, México.

${ }^{3}$ Centro de Investigacion y Estudios Avanzados (CINVESTAV) Unidad Monterrey, Instituto Politecnico Nacional, Apodaca, Nuevo León, México.

${ }^{4}$ Orthopedics and Traumatology Service, University Hospital “Dr. Jose Eleuterio Gonzalez”, Universidad Autónoma de Nuevo León (U.A.N.L.), Monterrey, Nuevo León, México.
} 
saphenous vein, remains an important option for bypass surgery due to the ease of obtaining and the abundant collateral circulation (Petrofski et al., 2004). The grafted vein segments usually have complications at medium and long term. When a vein segment is grafted to an arterial circulation, the acting biomechanical forces which stimulate the modification of its structure cause a hyperplasia of the wall in order to adapt and mimic the occluded arterial segment (Cooper et al., 1996). Unfortunately, this adaptive morphological response may progress to a point in which it occludes the lumen of the vascular graft, leading to graft failure (Parang \& Arora, 2009).

The hyperplasia occurs as a vessel response (artery or vein) to a structural lesion of the vascular wall, which is characterized by the development of a prominent internal elastic lamina and an increase in the production of extracellular matrix components. The effect is also accompanied by an increase in migration, proliferation, and apoptosis of smooth muscle cells (Petrofski et al.; Bäck et al., 2005).

The adaptive response of vein grafts has been previously studied, but the results are focused on medium and late stages of the process, we believe that the study of these changes at an early stage is important to elucidate the morphopathological mechanisms involved in graft failure. Our research group proposed a vein graft microsurgical model in Wistar rats, to study the graft adaptation (Cooper et al., 2000). The objective of this study was to characterize the early morphological response of the vascular wall in an end to end vascular vein graft model.

\section{MATERIAL AND METHOD}

This work was a morphological, experimental, crosssectional, descriptive and comparative study.

Ethical considerations. The experiments were conducted according to National Institutes of Health guide for the care and use of Laboratory animals, and according to the Mexican Legislature NOM-062-ZOO 1999 of the Technical Specifications for the Production, Care, and Use of Laboratory Animals. The protocol was approved by the Bioethics Committee of the institution with registration number AH13-001.

Biological Material. Twenty male, Wistar rats of 3 months of age, with a weight between 250 and 350 grams were used and kept on a standard laboratory diet with water ad libitum and light and dark cycles of 12 hours. The rats were divided into 4 groups ( $\mathrm{n}=5)$. Each group was analyzed in a different postoperative time: Group 1 was used as full control and the graft surgery was not performed, group 2 was analyzed at the 1 st postoperative day, group 3 on the 3 rd postoperative day, and group 4 until the 5 th postoperative day.

Microsurgical vein graft model. The model was performed according to the method described by Quiroga-Garza $e t$ al . (2011) with some modifications. Rats were anesthetized with ketamine (PISA, $82.5 \mathrm{mg} / \mathrm{kg}$ ) and xylazine (Vedilab, $10 \mathrm{mg}$ / $\mathrm{kg}$ ) administered intraperitoneally (i.p.). After obtaining an anesthetic plane, abdominal and bilateral inguinal region trichotomy was conducted. The surgical procedure began with an incision on the left inguinal region parallel to the long axis of the caudal extremity. The subcutaneous tissue was dissected, identifying the femoral neurovascular bundle proceeding to separate a segment of the femoral vein distal to the deep femoral vein and proximal to the superficial circumflex iliac vein. Ligation and extraction of a 6-8 millimeters in length segment was obtained and irrigated with heparinized saline to remove blood clots and the remnants from the lumen. We proceeded to make an incision in the right inguinal area, dissecting the femoral artery of the neurovascular bundle, caudal to the deep femoral artery and a microvascular approximator was placed to isolate the circulation (Fig. 1). Heparinized irrigation was performed after a cross section of the artery was done. The vein graft segment was reversed to continue the same direction of blood flow within the lumen and an end to end anastomosis was performed in both, the proximal and distal segments. Anastomoses were made with 8 single suture points placed symmetrically on the circumference of each end using a 100 suture polyamide (B|Braun Aesculap) (Fig. 2).

Upon completion of these vascular anastomoses, approximators were removed to restore blood circulation. Absence of bleeding from the anastomosis was verified. Any

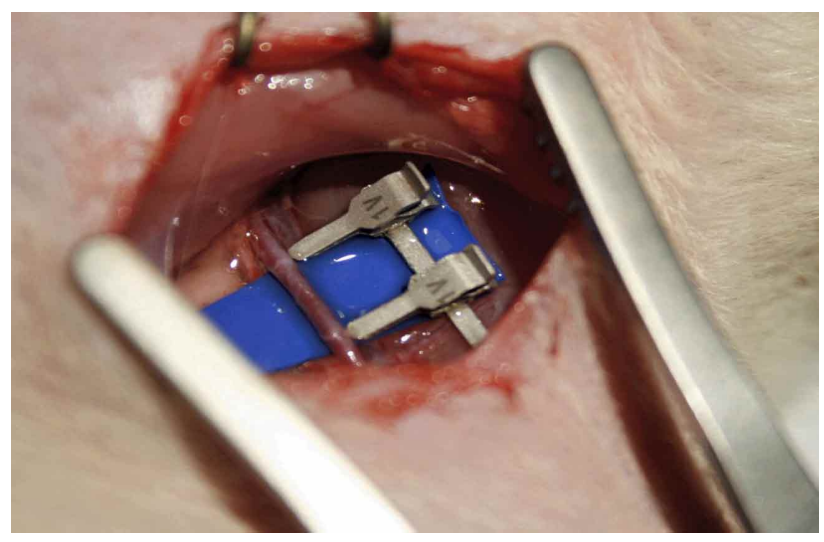

Fig. 1. Right inguial region dissection. The vascular approximator is placed next to the artery to verify the working area for the vein graft. 
VELAZQUEZ-GAUNA, S. E.; SOTO-DOMÍNGUEZ, A.; QUIROGA-GARZA, A; REYES-HERNÁNDEZ, C. G.; CHAVEZ-REYES, A.; MORALES-AVALOS R.; MONTES-DE-OCALUNA, R.; GUZMÁN-LÓPEZ, S. \& ELIZONDO-OMAÑA, R. E. Histomorphometric and immunohistochemical study of early adaptative response of the vascular wall in a termino-terminal microsurgical model of femoral vessels in wistar rat. Int. J. Morphol., 35(2):479-487, 2017.

bleeding was managed directly with gentle pressure for one minute, without occluding the vessel. If a pulsating bleeding was evident, an additional suture point was added for control. Subsequently, permeability tests were performed mechanically. The procedure was completed by suturing the two inguinal incisions with nylon 6-0 (B|Braun Aesculap).

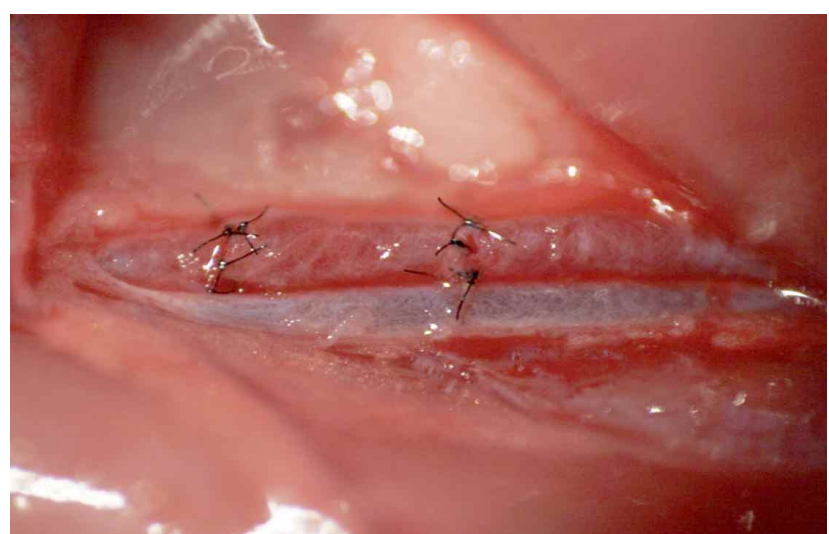

Fig. 2. The vein graft is visualized after its anastomoses with the femoral artery as part of the femoral bundle. Suture points are identified at each end.

The rats were monitored for the next $2 \mathrm{~h}$ to ensure complete recovery from anesthesia and to ensure absence of postoperative pain or suffering. In the following days, daily doses of heparin $(625 \mathrm{IU} / \mathrm{kg}$ ) were administered intramuscularly until the day of graft extraction. To prevent blood clotting of the graft, heparin (PISA $250 \mathrm{IU} / \mathrm{kg}$ ) was administered i.p. 30 minutes before the procedure (Lidman \& Daniel, 1981).

Collection and processing of the sample. The extraction of vein graft was obtained on postoperative days 1, 3 and 5 depending on the group; the rats were anesthetized and the sample extracted, afterwards, the rats were euthanized. Ungrafted control samples of the femoral vein were obtained from the control group. Samples were fixed in a solution of $4 \%$ paraformaldehyde in PBS $1 X$ solution ( $\mathrm{pH} 7.2-7.4)$ for 24 hours. These were then processed using conventional histological techniques until their inclusion in paraffin blocks to obtain $5 \mu \mathrm{m}$ transversal slices. To analyze the overall structure of vessel, hematoxylin and eosin and Masson trichrome were used to distinguish the collagen fibers, muscle fibers and cell nuclei in each of the vascular tunics.

Immunohistochemical analysis of cell proliferation, smooth muscle fibers, and macrophages. For immunohistochemical analysis, $4 \mu \mathrm{m}$ transversal sections were processed with monoclonal antibodies specific to antiPCNA (Proliferating Cell Nuclear Antigen) (1:200, Dako Cytomation, Inc.) to identify the cells in the S-phase indicating proliferation; anti-actin specific antibodies were used to identify smooth muscle cells (dilution 1: 100) and anti-CD68 to identify macrophages. Nuclei were counterstained with Mayer's haematoxylin. The detection system used was from LSAB technology + System-HRP (Link-Streptavidin-Biotin + System-Horseradish Peroxidase) (Abcam ${ }^{\circledR}$, Cambridge, MA). Tissue sections of colon were used as positive controls for cell proliferation, and tongue for muscle cells. Sections of brain tissue were used as negative controls for cell proliferation, and liver for smooth muscle cells.

Immunohistochemical analysis of TUNEL for identifying the fragmentation of chromatin. TUNEL technique was used (TdT-mediated dUTP-biotin Nick-End Labeling) to identify chromatin fragmentation, one of the events of the apoptosis phenomenon (St. André \& DelRossi, 2005). The technique was performed in histological sections of $7 \mu \mathrm{m}$ using the TACS.XL ${ }^{\circledR}$ DAB in situ Apoptosis Detection kit of Trevigen ${ }^{\circledR}$ (Gaithersburg, MD) according to the instruction of the distributer, counterstaing the nuclei with methyl green. As a positive control, liver sections nuclease-treated were used to induce DNA fragmentation observing a brown color in the nuclei of the positive cells. As negative control, the enzyme TdT (terminal deoxynucleotidyl transferase) was replaced with distilled water. The samples were analyzed by two different morphologist specialists, using a light microscope Nikon Eclipse 50i and an image analysis system with NIS-elements advanced research Digital Sight DDS2Mu software and Image J software, version 1.49 (National Institutes of Health).

Morphometric analysis. Morphometric determinations concerning various characteristic aspects of early morphological adaptation of the vessels in the experimental and control groups were performed as follows:

Analysis of the thickness of the vascular tunics. In the slides stained with Masson trichrome method, measurements of the intima and media tunics were performed. The NISelements advanced research Digital Sight DDS-2Mu software was used with a high power objective 40x objective in the light microscope.

Micro-densitometric analysis of smooth muscle cells. The micro-densitometric analysis of the proportion of immunopositive smooth muscle fibers in the samples was performed as follows: high resolution digital images of 10 consecutive fields were obtained with the high power objective (40x). The parameters of color, distribution of tonality, saturation and luminance were established in the data software and were the same for all the images obtained. Subsequently the images were analyzed with Image J 1.49V 
VELAZQUEZ-GAUNA, S. E.; SOTO-DOMÍNGUEZ, A.; QUIROGA-GARZA, A; REYES-HERNÁNDEZ, C. G.; CHAVEZ-REYES, A.; MORALES-AVALOS R.; MONTES-DE-OCALUNA, R.; GUZMÁN-LÓPEZ, S. \& ELIZONDO-OMAÑA, R. E. Histomorphometric and immunohistochemical study of early adaptative response of the vascular wall in a termino-terminal microsurgical model of femoral vessels in wistar rat. Int. J. Morphol., 35(2):479-487, 2017.

(NIH) to quantify the amount by microdensitometry of smooth muscle cells in positive immunostaining. From the images obtained, the dark brown tonality fibers were selected manually, and the program (previously calibrated with the detection threshold of a control sample) converted the color interval to grayscale, and all other tissue components to a white color. Subsequently, the processed images were automatically analyzed to determine the percentage of the area and intensity of the density (Int Dent) of muscle fibers in each sample. This was performed in triplicate.

Quantification of cell number in proliferation and apoptosis. PCNA positive cells were identified and quantified in each of the 10 consecutive vascular tunics $40 \mathrm{x}$ fields per slide in 5 animals per group, for a total of 50 fields per group. This was done using the plug-in cell counter from the Image J $1.49 \mathrm{~V}(\mathrm{NIH})$ program. Initially the same methodology to quantify TUNEL-positive nuclei in the samples of the study groups was proposed, but this was not done due to the absence of apoptosis in the samples analyzed.

Statistical analysis. For the morphometric analysis, the mean and standard deviation were obtained for statistical analysis and comparison of the study groups. The total of the values obtained from the micro-densitometric quantization was captured in IBM SPSS Statistics Version 21.0 (Chicago, IL, USA). Parametric correlation tests (twotailed t Student test) were performed considering as a significant $\mathrm{p}$ value $\leq 0.05$

\section{RESULTS}

Early adaptive morphological changes in the vein graft segments in a microsurgical model. The results obtained from the analysis of vein grafts in light microscopy from groups samples at 1, 3 and 5 postoperative days were compared against absolute controls. The control group showed a continuous layer of endothelium on the surface and endothelial cells were seen in contact with the lumen, which rests on a well-defined internal elastic lamina. The typical thin tunica media of a vein, elongated spindle cells were observed with oval nuclei and characteristics of smooth muscle cells arranged around the lumen. The adventitia demonstrated variable thickness and tears due to the process of blunt dissection (Fig. 3A). In the samples analyzed with Masson's trichrome method, the media and adventitia were well defined, showing the tunica media with a bright red color due to the presence of smooth muscle cells, and the adventitia with a blue staining indicative of collagen bundles (Fig. 3B).

Samples of vein grafts from the postoperative day 1 showed partial endothelial denudation; denuded regions were covered by a carpet of platelets, occasional microthrombi and leukocytes. An increase in the thickness of the tunica intima and a decrease in the thickness of the tunica media was also observed (Table I). General disarray in the elements that composes them was evident as well as boundaries between the tunics that were not easily appreciable. In the tunica media, smooth muscle cells were observed as well as several well-defined elastic fibers. The adventitia showed the presence of cellular infiltrate with a predominancy for leukocytes and macrophages (Figs. 3C and 3D).

The sections from the postoperative day 3 showed an endothelial denudation similar to that observed in day 1 samples. A higher tunica intima and media thickening was observed in comparison to the first postoperative day (Table I). Likewise, it was difficult to distinguish the intima. However, an increase in the amount of smooth muscle cells was observed. In the tunica media, the number of smooth muscle cells was increased compared with the other two days of study (1 and 5). The elastic fibers were slightly disorganized and neither followed a particular direction. In the adventitia an increase in the number of infiltrating cells (macrophages and leukocytes) was observed (Figs. 3E and 3F).

On postoperative day 5, total denudation of endothelium was observed. The tunica intima and media showed greater thickness than the observed on postoperative days 1 and 3 (Table I). In these samples the intima was difficult to distinguish. In the tunica media, cell nuclei of smooth muscle were observed and the elastic fibers lost continuity and were disorganized. The presence of cellular infiltrate in the tunica media and adventitia was observed in between these, making it difficult to distinguish the tunica limits (Figs. 3G and $3 \mathrm{H})$. In all periods analyzed, extracellular fluid was detected, the greatest amount being in the fifth postoperative day. This liquid was observed as an aggregate of eosinophilic, amorphous acellular staining (data not shown).

Table I. Tunic morphometric measurements (all measurement in $\mu \mathrm{m}$ ).

\begin{tabular}{lcccc}
\hline & Control & $1^{\text {st }}$ PO Day & $3 \mathrm{r}^{\mathrm{d}}$ PO Day & $5^{\text {th }}$ PO Day \\
\hline tima & $16.52 \pm 2.11$ & $19.13 \pm 4.13$ & $29.48 \pm 12.79$ & $31.51 \pm 10.09$ \\
edia & $37.30 \pm 4.53$ & $26.28 \pm 7.48$ & $34.30 \pm 9.77$ & $43.43 \pm 14.02$ \\
otal & $53.82 \pm 2.45$ & $45.41 \pm 5.80$ & $63.78 \pm 11.04$ & $74.94 \pm 14.17$ \\
\hline
\end{tabular}


VELAZQUEZ-GAUNA, S. E.; SOTO-DOMÍNGUEZ, A.; QUIROGA-GARZA, A; REYES-HERNÁNDEZ, C. G.; CHAVEZ-REYES, A.; MORALES-AVALOS R.; MONTES-DE-OCALUNA, R.; GUZMÁN-LÓPEZ, S. \& ELIZONDO-OMAÑA, R. E. Histomorphometric and immunohistochemical study of early adaptative response of the vascular wall in a termino-terminal microsurgical model of femoral vessels in wistar rat. Int. J. Morphol., 35(2):479-487, 2017.
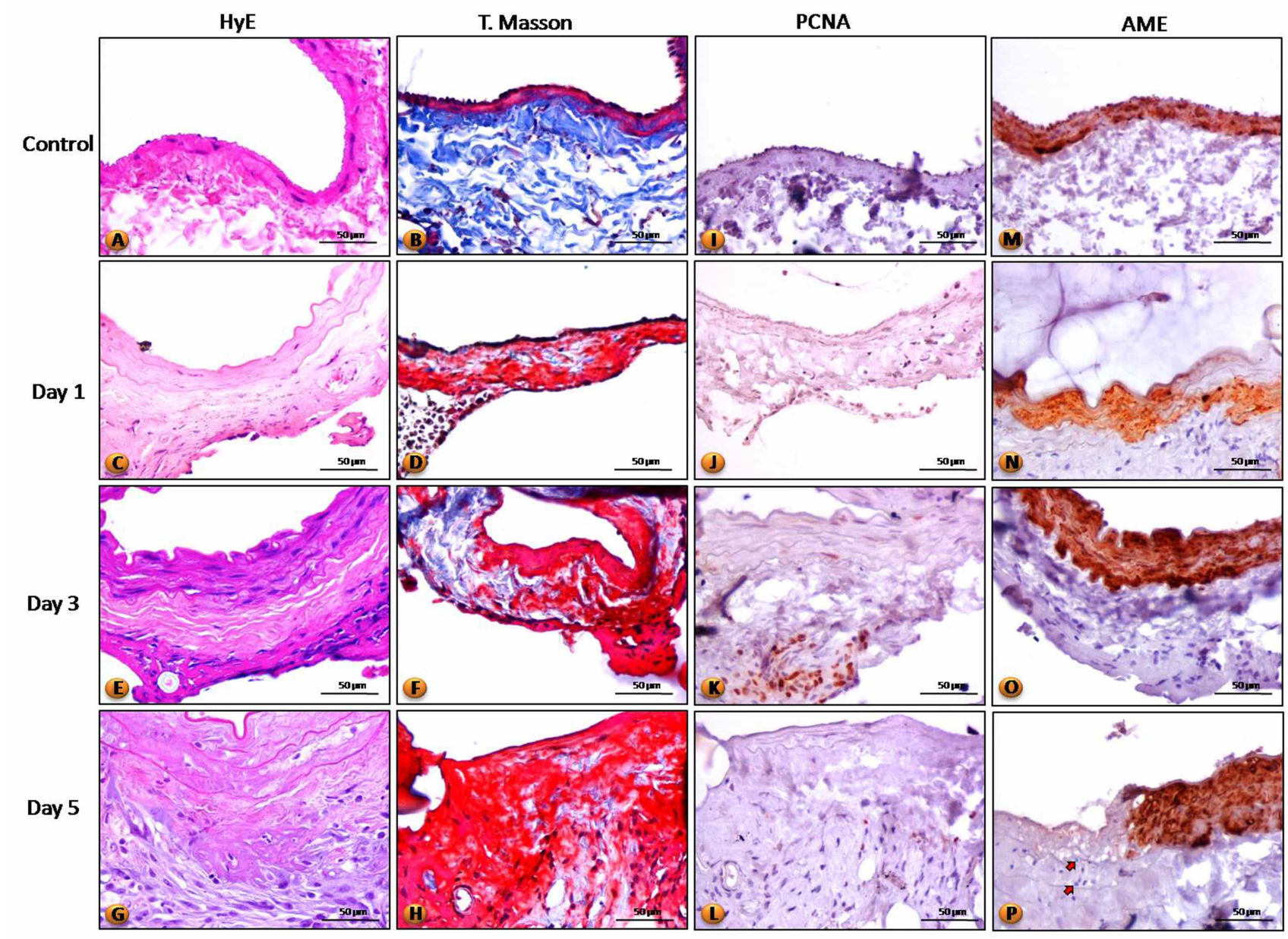

Fig. 3. Vein grafts. A-B) Control Group. Intima tunic with endothelial cells resting on a well-defined internal elastic lamina. Tunica media with thin, elongated spindle cells with oval nuclei. Adventitia with varying thickness. The middle and adventitia tunics stained bright red and blue respectively with Masson trichrome. C-D) Graft day 1: increased thickness and disruption of the middle and adventitia tunics. Cellular infiltrate is observed in the adventitia. E-F) Graft day 3: Increased thickness and disorganization compared to day 1. Presence of increased infiltrating cell in the adventitia. G-H) Graft day 5: Increased thickness of the media and adventicia compared to day 1 and 3. Scattered infiltrating cells are observed in the media. Cell proliferation in vein grafts. I) Control Group. Negative results are observed for cell proliferation. J) Graft day 1: few positive cells in the adventitia. K) Graft days 3: increase in positive cells in media and adventitia. L) Graft day 5: reduction of proliferating cells, some positive cells in the adventitia. Positive cells (red arrows). Increased smooth muscle fibers. M) Absolute Control: homogeneous positivity in the vascular wall of the tunica media. N, O, P) Bypass Grafts 1, 3 and 5 days show positivity for muscle cells in the tunica media. There are areas absent of actin in all time periods analyzed, in sites near these areas the presence of infiltrating cells were found (red arrows).

Analysis and quantification of cellular proliferation in venous grafts. The femoral venous grafts as well as controls underwent immunohistochemistry to detect the presence of cell proliferation though PCNA. Rat colon sections were used as positive controls of cell proliferation, staining brown the nuclei in the cells from the Lieberkühn crypts. Brain tissue was used as a negative control, with no evidence of cell proliferation.

In analyzing the absolute control of femoral vein segments, low cell proliferation was found $(2.66 \%)$ (Fig. 3I). However, in the vein grafts from the first postoperative day, few positive cells were found in the tunica adventitia $(12.66 \%)$ (Fig. 3J). The number of proliferating cells increased significantly by the third postoperative day, finding positive cells in both the adventitia and the media (40\%) (Fig. 3K). By the fifth postoperative day, the number of cells positive for proliferation decreased, because they were found in the adventitia region only (16.33\%) (Fig. 3L).

Early adaptive morphological changes of smooth muscle cells. Immunostaining of smooth muscle cells in the tunics of the vein graft was performed by using anti-actin antibodies specific for muscle. As a positive control, rat 
VELAZQUEZ-GAUNA, S. E.; SOTO-DOMÍNGUEZ, A.; QUIROGA-GARZA, A; REYES-HERNÁNDEZ, C. G.; CHAVEZ-REYES, A.; MORALES-AVALOS R.; MONTES-DE-OCALUNA, R.; GUZMÁN-LÓPEZ, S. \& ELIZONDO-OMAÑA, R. E. Histomorphometric and immunohistochemical study of early adaptative response of the vascular wall in a termino-terminal microsurgical model of femoral vessels in wistar rat. Int. J. Morphol., 35(2):479-487, 2017.

tongue sections were used to distinguish the positivity, which was brown. As negative control, liver sections were used, in which the presence of muscle cells was not found.

The absolute control of the femoral vein segments showed positive immunohistochemical test, observing a thin strip, homogeneously distributed in the vascular wall, corresponding to the zone of the tunica media (Fig. 3M). The vein grafts from the three different postoperative times demonstrated positivity for muscle cells in the area of the tunica media (Figs. 3N-P). An important finding was that all areas lacking actin positive cells were observed with the presence of infiltrating cells (macrophagues and leukocytes).
Analysis of apoptosis by TUNEL. In analyzing the controls and venous grafts samples at postoperative days 1, 3, and 5 with TUNEL, no positivity was observed for chromatin fragmentation, a phenomenon that occurs during apoptosis.

Morphometric adaptive changes in the thickness and composition of the tunics in vein grafts. Results of the tunic morphometric measurements are shown in Table I. The results of the $t$ Student test showed no significant difference between control and the postoperative day 1 concerning the intima. Nevertheless, when comparing control versus postoperative days 3 and 5 significant difference
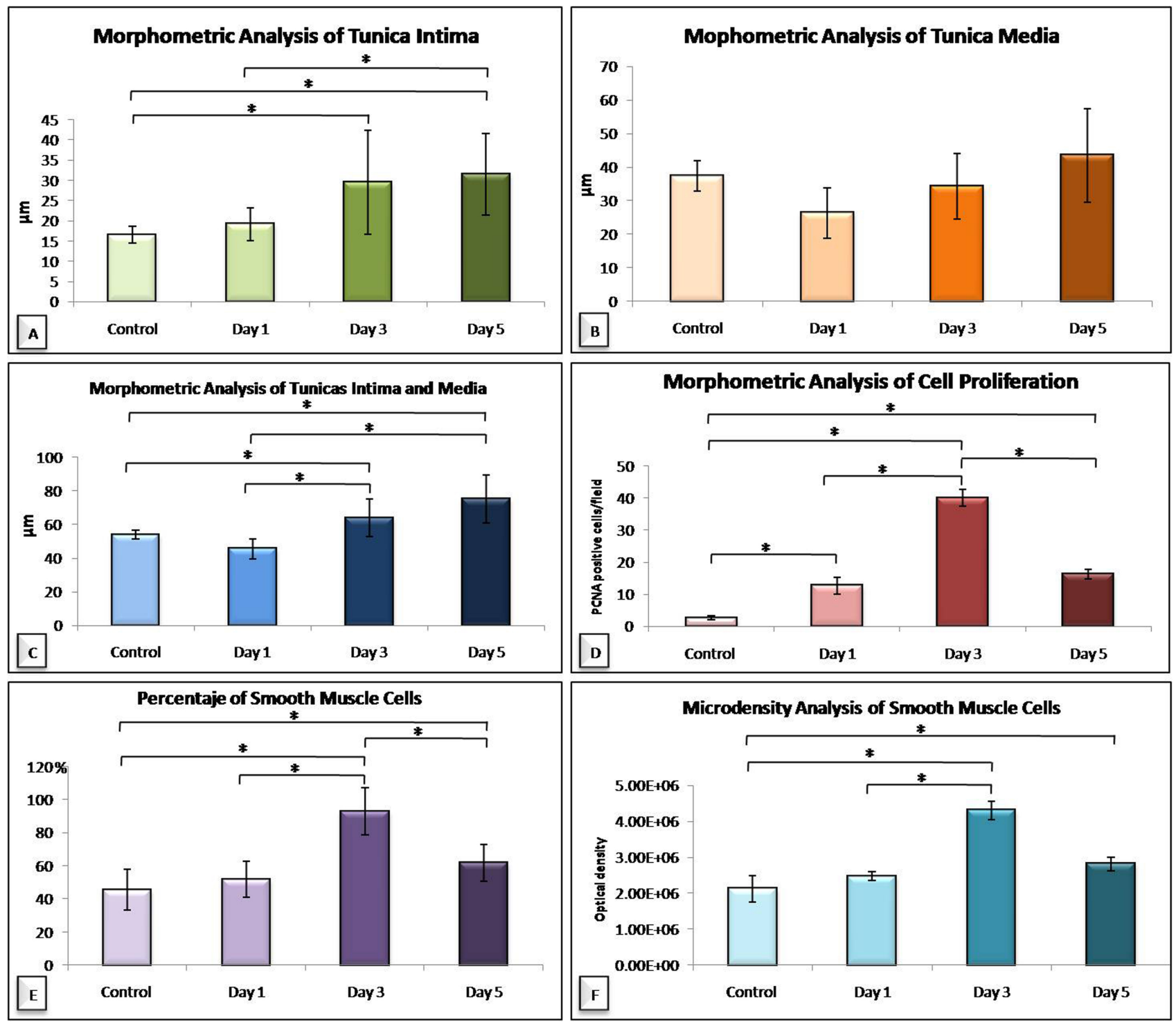

Fig. 4. A) Morphometric analysis of the intima in the study groups. B) Morphometric analysis of the tunica media. C) Analysis of the vascular layers (intima and media). D) Morphometry of cells positive to PCNAs/field. E) Percentage of area occupied by smooth muscle fibers.. F) Micro-densitometric analysis of smooth muscle fibers group. $*(p \leq 0.05)$. 
VELAZQUEZ-GAUNA, S. E.; SOTO-DOMÍNGUEZ, A.; QUIROGA-GARZA, A; REYES-HERNÁNDEZ, C. G.; CHAVEZ-REYES, A.; MORALES-AVALOS R.; MONTES-DE-OCALUNA, R.; GUZMÁN-LÓPEZ, S. \& ELIZONDO-OMAÑA, R. E. Histomorphometric and immunohistochemical study of early adaptative response of the vascular wall in a termino-terminal microsurgical model of femoral vessels in wistar rat. Int. J. Morphol., 35(2):479-487, 2017.

was evident ( $\mathrm{p}=0.03$ and 0.01 respectively) (Fig. 4A). The tunica media had no significant difference in any of the groups (Fig. 4B). When comparing the total tunic thinckness (intima and media), no significant difference between control and the postoperative day 1 was observed, but when comparing control versus postoperative days 3 and 5 significant difference was evident $(p=0.02$ and 0.01 respectively) (Fig. 4C).

When quantifying PCNA-positive cells, values of $2.66 \% \pm 0.57$ for the control group and, $12.66 \% \pm 2.51,40.00$ $\% \pm 2.64$ and $16.33 \% \pm 1.52$ were obtained, for the first, third and fifth postoperative day respectively (Fig. 4D). Between the control group and the other postoperative times, there were significant differences $(p=<0.001$ in all cases).

The percentage of area occupied by smooth muscle cells in the vascular tunics were: $45.44 \% \pm 12.30,51.77 \%$ $\pm 10.90,92.80 \% \pm 14.30$, and $61.69 \% \pm 10.93$ for the control sample, first, third and fifth postoperative days respectively (Fig. 4E). There were significant differences between the control group with postoperative days $3(\mathrm{p}=0.01)$ and 5 $(\mathrm{p}=0.02)$.

As for the intensity of density, values found were: $2.13 \mathrm{E}+06 \pm 3.65 \mathrm{E}+05$ for the control group, $2.48 \mathrm{E}+06$ $\pm 1.24 \mathrm{E}+05$ for the postoperative day 1 group, 4.30E+06 $\pm 2.55 \mathrm{E}+05$ for the postoperative day 3 group, and $2.82 \mathrm{E}+06$ $\pm 1.90 \mathrm{E}+05$ for the postoperative day 5 group (Fig. 4F). There were significant differences between the control group with postoperative days $3(\mathrm{p}=0.002)$ and $5(\mathrm{p}=0.02)$.

\section{DISCUSSION}

The results obtained in this study identify early adaptive morphological changes in the structure of the femoral vein graft wall in a murine microsurgical model with evaluation days 1, 3 and 5 after its autogenous graft using the contralateral vessel in male Wistar rats.

In this experimental model, the structure, composition, and morphological changes of femoral vein segments grafted were analyzed. Development, improvement, and characterization of this animal model study has important implications in the study of the vascular graft adaptive response and intimal hyperplasia (Cooper et al., 2000). A better understanding of these processes, such as the characteristics, mechanisms, and molecules involved, is needed in order to establish possibletherapeutic targets suitable for treating this condition.
There are several animal models for the study of adaptive response in vascular conduits (Cooper et al., 2000); these have some common characteristics to what happens in (Lidman \& Daniel; Zwolak et al., 1987; Motwani \& Topol, 1998). However, surgical procedures vary from one model to another, although these do not work the same way as in vascular graft surgery (Cooper et al., 1996; Zou et al., 1998).

Our microsurgical model had three important features: 1) An adequate gauge with an artery-vein ratio of approximately $1.5: 1,2$ ) Uncomplicated access and handling of the graft, as the femoral vessels were easily located and easy to dissect from the subcutaneous tissue of the groin, and 3) Vascular morphology similar in composition to humans.

During vein graft surgery there is exposure of collagen fibers in the vessel wall to circulating platelets in the area of the anastomosis, the coagulation cascade is activated; For this reason, a therapy administering heparin as anticoagulant thirty minutes before each surgery and then every day afterwards was established, until graft extract for analysis (St. André \& DelRossi).

Moreover, in morphological studies analyzed by light microscopy, the control segments and venous grafts showed scarce tunica intima and few endothelial cells lining the vascular lumen; it has been reported that there is loss in the venous endothelium from mechanical trauma segments produced by manipulation of the vein during dissection, prior to the bypass surgery (Zhu et al., 2011; Owens et al., 2015).

Studies using transmission electron microscopyhave reported that between 1 and 4 hours after graft surgery, there is evidence of endothelial damage with cell loss, and the internal elastic lamina is observed as a discontinuous and amorphous line of elastin. This study also states that the intima tunic begins to increase until 6th postoperative week (Stark et al., 1997). This would explain why we observed a denuded endothelium as well as the difficulty to distinguish the intima in the postoperative days 1,3 and 5 .

The analysis of vein grafts also confirmed a gradual increase in the thickness and disarray in the organization of the components of the tunica media in postoperative days 1 to 5. This increase in the thickness of the media tunic may be due to the migration and proliferation of muscle cells or their precursors into the vascular graft wall (Diao et al., 2008).

It is likely that the gradual disruption in the composition of the media and adventitia tunics is related to the activity of metalloproteinase enzymes 2 and 9 (Lessner $e t$ al., 2004), which degrade collagen and elastin to allow the 
VELAZOUEZ-GAUNA, S. E.; SOTO-DOMÍNGUEZ, A.; QUIROGA-GARZA, A; REYES-HERNÁNDEZ, C. G.; CHAVEZ-REYES, A.; MORALES-AVALOS R.; MONTES-DE-OCALUNA, R.; GUZMÁN-LÓPEZ, S. \& ELIZONDO-OMAÑA, R. E. Histomorphometric and immunohistochemical study of early adaptative response of the vascular wall in a termino-terminal microsurgical model of femoral vessels in wistar rat. Int. J. Morphol., 35(2):479-487, 2017.

free flow of smooth muscle cells through extracellular matrix from the adventitia and media towards the neointima (Mavromatis et al., 2000). In all postoperative times, we observed the presence of infiltrating cells (macrophages) in the adventicia and in postoperative day 5 in the tunica media.

The presence of these macrophages and leukocytes from the first postoperative day and the extracellular fluid found in samples from all time periods studied, suggest the existence of an inflammatory process in the vascular wall, due to the damage during the surgical procedure as well as the cellular detritus exchange process afterwards (Rodriguez et al., 2000; Schachner et al., 2006). These could contribute directly to the thickening of the tunicas media and adventitia of vein graft.

The results of our study showed that from the first postoperative day, proliferating cells were found in the vascular wall of the graft, having a peak of proliferation on day 3. Other studies reported the presence of new smooth muscle cells within the first 24-36 hours after bypass surgery (O'Brien et al., 1997; Kalra \& Miller, 2000). In graft samples analyzed, it was observed that the location of proliferating cells at the first postoperative day correspond to the area of the tunica adventitia, then the third and fifth day these cells were found in the tunica media and adventicia. This suggests that the cells proliferate, but are also migrating to where the intima regenerates (Kalra $\&$ Miller). The technique utilized in this study for the measurement of cell proliferation can not distinguish between the smooth muscle cells proliferation and other cellular components, which could be considered a limitation. However, the results of analysis of intensity of the density and the area occupied by smooth muscle cells observed match with the peak in cell proliferation, so we conclude that this proliferation is mainly because of the smooth muscle component.

Through immunohistochemical methods, the distribution pattern of smooth muscle cells was analyzed for morphological alterations and found that at the time periods tested, these cells were confined only to the tunica media. It was an interesting finding that the areas in the tunica media did not test positive for actin. Reviewing these areas in more detail, we observed that the areas nearby without actin had scattered infiltrating cells, which, as mentioned above are indicative of an inflammatory process.

TUNEL assays at the early periods of time of 1, 3 and 5 postoperative days, showed no positivity for fragmentation of chromatin in cells of the vascular wall of vein grafts. This could be explained with other studies that found that the apoptosis peak occurs in the first 8 hours after the procedure and declines towards baseline by 24 to 48 hours (Rodriguez et al.).
Currently in our laboratory, studies are carried out to elucidate the cellular and adaptive changes in further times to those analyzed in this study, as well as the use of molecular strategies to inhibit hyperplasia of the tunics in this microsurgical model of vein graft.

The results shown in this project focused on short postoperative times. Our results support and extend the results reported by previous studies. There is progressive increase of cell proliferation and intensity of the density detected by PCNA with its peak at postoperative day 3. Apoptosis was not evident. Smooth muscle had no significant change in any the time periods studied. Macrophage and leukocyte migration was evident in all times studied.

This study characterizes the morphological aspects in the early arterialization of the vascular wall in a vein graft process. Our results contribute to a better understanding of the morphopathological mechanism involved in vein graft failure. This model could be use in future therapeutic trials in animal models.

ACKNOWLEDGEMENTS. We acknowledge Luis Botello I. Soto and Lorenzo Castaneda Rada for their technical assistance during the sample processing.

VELAZQUEZ-GAUNA, S. E.; SOTO-DOMÍNGUEZ, A.; QUIROGA-GARZA, A; REYES-HERNÁNDEZ, C. G.; CHAVEZ-REYES, A.; MORALES-AVALOS R.; MONTESDE-OCA-LUNA, R.; GUZMÁN-LÓPEZ, S. \& ELIZONDOOMAÑA, R. E. Estudio histomorfométrico e inmunoistoquímico de la respuesta adaptativa temprana de la pared vascular en un modelo microquirúrgico termino-terminal de los vasos femorales en rata wistar. Int. J. Morphol., 35(2):479-487, 2017.

RESUMEN: Cuando un segmento venoso es injertado dentro de la circulación arterial, se generan fuerzas biomecánicas que estimulan modificaciones en su estructura. Esta respuesta morfológica adaptativa es progresiva a mediano y largo plazo y termina por ocluir la luz del vaso, conduciendo a la falla del injerto. El objetivo de este estudio fue caracterizar la respuesta morfológica adaptativa temprana de la pared vascular en un modelo de injerto vascular venoso termino-terminal en ratas Wistar. Un segmento de la vena femoral se coloco en la circulación arterial femoral. Una anastomosis del injerto microquirúrgica termino-terminal fue implementada y estandarizada en veinte ratas. Las muestras se procesaron con la técnica histológica para analizar su estructura general con la tinción de hematoxilina y eosina, la composición de la pared vascular con la técnica de tricromico de Masson , la proliferación y las células de musculo liso fueron detectadas mediante técnicas inmunohistoquimicas (anti PCNA, anti-actina y anti CD68) y la inducción de la apoptosis mediante la técnica de TUNEL. Los tiempos de estudio fueron al día 1,3 y 5 
VELAZQUEZ-GAUNA, S. E.; SOTO-DOMÍNGUEZ, A.; QUIROGA-GARZA, A; REYES-HERNÁNDEZ, C. G.; CHAVEZ-REYES, A.; MORALES-AVALOS R.; MONTES-DE-OCALUNA, R.; GUZMÁN-LÓPEZ, S. \& ELIZONDO-OMAÑA, R. E. Histomorphometric and immunohistochemical study of early adaptative response of the vascular wall in a termino-terminal microsurgical model of femoral vessels in wistar rat. Int. J. Morphol., 35(2):479-487, 2017.

postoperatorios. Hay un incremento progresivo en la proliferación celular y la intensidad de la densidad detectado mediante PCNA con un pico en el día 3 postoperatorio. La apoptosis no fue evidente en ninguno de los días postoperatorios. Las células de musculo liso no tuvieron un cambio significativo en ninguno de tiempos de estudio. La migración de macrófagos y leucocitos fue evidente desde el primer día postoperatorio con infiltración a la túnica media al $5^{\text {to }}$ día. Conclusiones. Este estudio caracteriza los aspectos morfológicos en el proceso de arterialización temprana de la pared vascular en un injerto venoso. Estos resultados contribuyen al mejor entendimiento de los mecanismos morfopatológicos envueltos en la falla del injerto venoso.

PALABRAS CLAVE: Hiperplasia; Morfologia; Modelo microquirúrgico; Cambios adaptativos vasculares; Injerto venoso.

\section{REFERENCES}

Aguirre-Rivero, R. Tratado de Cirugía General. Ciudad de México, Editorial El Manual Moderno, 2003.

Bäck, M.; Bu, D. X.; Bränström, R.; Sheikine, Y.; Yan, Z. Q. \& Hansson, G. K. Leukotriene B4 signaling through NF-kappaB-dependent BLT1 receptors on vascular smooth muscle cells in atherosclerosis and intimal hyperplasia. Proc. Natl. Acad. Sci. U. S. A., 102(48):17501-6, 2005.

Cooper, G. J.; Underwood, M. J. \& Deverall, P. B. Arterial and venous conduits for coronary artery bypass. A current review. Eur. J. Cardiothorac. Surg., 10(2):129-40, 1996.

Cooper, R.; Cutler, J.; Desvigne-Nickens, P.; Fortmann, S. P.; Friedman, L.; Havlik, R.; Hogelin, G.; Marler, J.; McGovern, P.; Morosco, G.; Mosca, L.; Pearson, T.; Stamler, J.; Stryer, D. \& Thom, T. Trends and disparities in coronary heart disease, stroke, and other cardiovascular diseases in the United States: findings of the national conference on cardiovascular disease prevention. Circulation, 102(25):3137-47, 2000.

Diao, Y.; Guthrie, S.; Xia, S. L.; Ouyang, X.; Zhang, L.; Xue, J.; Lee, P.; Grant, M.; Scott, E. \& Segal, M. S. Long-term engraftment of bone marrow-derived cells in the intimal hyperplasia lesion of autologous vein grafts. Am. J. Pathol., 172(3):839-48, 2008.

Elizondo-Omaña, R. E.; García-Rodríguez, M. A.; Morales-Gómez, J. A.; Guzmán-López, S.; Tijerina de la Garza, O.; Fernandez-Rodarte, B.; Montermayor-Flores, M. L. \& Herrera-Meléndez, J. Conductos vasculares utilizados en la operación de revascularización miocárdica. Med. Univ., 7(29):222-5, 2005.

Isselbacher, K. J.; Braunwald, E. \& Wilson, J. D. Harrison. Principles of Internal Medicine. $13^{\text {th }}$ ed. Ciudad de México, Mc Graw Hill Interamericana, 1994.

Kalra, M. \& Miller, V. M. Early remodeling of saphenous vein grafts: proliferation, migration and apoptosis of adventitial and medial cells occur simultaneously with changes in graft diameter and blood flow. $J$. Vasc. Res., 37(6):576-84, 2000

Lessner, S. M.; Martinson, D. E. \& Galis, Z. S. Compensatory vascular remodeling during atherosclerotic lesion growth depends on matrix metalloproteinase-9 activity. Arterioscler. Thromb. Vasc. Biol., 24(11):2123-9, 2004.

Lidman, D. \& Daniel, R. K. The normal healing process of microvascular anastomoses. Scand. J. Plast. Reconstr. Surg., 15(2):103-10, 1981.

Mavromatis, K.; Fukai, T.; Tate, M.; Chesler, N.; Ku, D. N. \& Galis, Z. S. Early effects of arterial hemodynamic conditions on human saphenous veins perfused ex vivo. Arterioscler. Thromb. Vasc. Biol., 20(8):188995, 2000.

Motwani, J. G. \& Topol, E. J. Aortocoronary saphenous vein graft disease: pathogenesis, predisposition, and prevention. Circulation, 97(9):916-
31, 1998.

O'Brien, J. E. Jr.; Shi, Y.; Fard, A.; Bauer, T.; Zalewski, A. \& Mannion, J. D. Wound healing around and within saphenous vein bypass grafts. $J$. Thorac. Cardiovasc. Surg., 114(1):38-45, 1997.

Owens, C. D.; Gasper, W. J.; Rahman, A. S. \& Conte, M. S. Vein graft failure. J. Vasc. Surg., 61(1):203-16, 2015.

Parang, P. \& Arora, R. Coronary vein graft disease: pathogenesis and prevention. Can. J. Cardiol., 25(2):e57-62, 2009.

Petrofski, J. A.; Hata, J. A.; Gehrig, T. R.; Hanish, S. I.; Williams, M. L.; Thompson, R. B.; Parsa, C. J.; Koch, W. J. \& Milano, C. A. Gene delivery to aortocoronary saphenous vein grafts in a large animal model of intimal hyperplasia. J. Thorac. Cardiovasc. Surg., 127(1):27-33, 2004.

Quiroga-Garza, A.; Delgado-Brito, M.; Bazaldúa-Cruz, J. J.; VillarrealSilva, E.; Velázquez-Gauna, S. E.; Elizondo-Omaña, R. E. \& GuzmánLópez, S. New microsurgical model for the study of the morphological adaptative response of venous grafts. Rev. Invest. Clin., 63(4):399-406, 2011

Rodriguez, E.; Lambert, E. H.; Magno, M. G. \& Mannion, J. D. Contractile smooth muscle cell apoptosis early after saphenous vein grafting. Ann. Thorac. Surg., 70(4):1145-53, 2000.

Schachner, T.; Laufner, G. \& Bonatti J. In vivo (animal) models of vein graft disease. Eur. J. Cardiothorac. Surg., 30(3):451-63, 2006.

Schwartz, S. I. Principles of Surgery. $3^{\text {rd }}$ ed. Ciudad de México, Interamericana Mc Graw Hill, 1995.

St. André, A. C. \& DelRossi, A. Hemodynamic management of patients in the first 24 hours after cardiac surgery. Crit. Care Med., 33(9):2082-93, 2005.

Stark, V. K.; Warner, T. F. \& Hoch, J. R. An ultrastructural study of progressive intimal hyperplasia in rat vein grafts. J. Vasc. Surg., 26(1):94103, 1997.

Zhu, Z. T.; Jiang, X. S.; Wang, B. C.; Meng, W. X.; Liu, H. Y. \& Tian, Y. Andrographolide inhibits intimal hyperplasia in a rat model of autogenous vein grafts. Cell Biochem. Biophys., 60(3):231-9, 2011.

Zou, Y.; Dietrich, H.; Hu, Y.; Metzler, B.; Wick, G. \& Xu, Q. Mouse model of venous bypass graft arteriosclerosis. Am. J. Pathol., 153(4):130110, 1998.

Zwolak, R. M.; Adams, M. C. \& Clowes, A. W. Kinetics of vein graft hyperplasia: association with tangential stress. J. Vasc. Surg., 5(1):12636, 1987.

\section{Corresponding Author:}

Santos Guzmán López M.D, PhD.

Department of Human Anatomy

Faculty of Medicine

Universidad Autónoma de Nuevo León (U.A.N.L.).

Av. Madero y Dr. Eduardo Aguirre Pequeño s/n

Col. Mitras Centro

Monterrey

Nuevo León CP. 64460

MÉXICO

\section{E-mail: rodolfot59@hotmail.com}

Received: 10-01-2017

Accepted: 08-03-2017 